\title{
Interannual variability in fatty acid composition of the copepod Neocalanus plumchrus in the Strait of Georgia, British Columbia
}

\author{
Rana El-Sabaawi ${ }^{1,5, *}$, John F. Dower ${ }^{1,2}$, Martin Kainz ${ }^{1,3}$, Asit Mazumder ${ }^{1,4}$ \\ ${ }^{1}$ Department of Biology, University of Victoria, PO Box 3020, Station CSC, Victoria, British Columbia V8W 3N5, Canada \\ ${ }^{2}$ School of Earth and Ocean Sciences, University of Victoria, PO Box 3055, Station CSC,Victoria, British Columbia V8W 3P6, \\ Canada \\ ${ }^{3}$ Danube University Krems, Interuniversity Center for Aquatic Ecosystem Research, Wasser Cluster Lunz Biological Station, \\ Dr. Carl Kupelwieser Promenade 5, 32932 Lunz am See, Austria \\ ${ }^{4}$ Water and Aquatic Sciences Research Program, University of Victoria, PO Box 3020, Station CSC, Victoria, BC V8W 3N5, \\ Canada \\ ${ }^{5}$ Present address: Ecology and Evolutionary Biology, 203E Corson Hall, Cornell University, Ithaca, NewYork 14853, USA
}

\begin{abstract}
Although food quality is thought to play an important role in the survival of marine organisms, the extent of natural variability in food quality over long time scales remains poorly characterized. We present a 6 yr time series of fatty acid data from the calanoid copepod Neocalanus plumchrus, an important contributor to mesozooplankton biomass in the Strait of Georgia and the northeast Pacific Ocean. Fatty acid profiles indicate significant spatiotemporal differences in the diet of this copepod. Spatially, oceanic specimens display fatty acid signatures characteristic of omnivorous copepods while coastal animals display primarily herbivorous, diatom-based signatures. Temporally, the fatty acid profiles of coastal $N$. plumchrus shifted from an omnivorous oceanic diet to an herbivorous, diatom-based diet between 2001 and 2006. The ratio of diatom to flagellate fatty acid markers increased over time, peaking from 2005 to 2006. The composition of flagellate markers also changed from primarily dinoflagellate markers (rich in docosohexaeonic acid) to green algal markers (poor in this essential fatty acid). The diet of $N$. plumchrus as deduced from fatty acids correlates with phytoplankton community composition. The abundance of coastal N. plumchrus in the Strait of Georgia was strongly correlated with the ratio of docosahexaeonic acid to eicosapentaeonic acid in the lipids of these copepods. We also discuss the potential for an imbalance of essential fatty acids supplied by a diatom-rich diet to limit the growth and survival of N. plumchrus in the Strait of Georgia.
\end{abstract}

KEY WORDS: Copepod · Diapause $\cdot$ Diet $\cdot$ Docosahexaeonic acid $\cdot$ Eicosapentaeonic acid · DHA · EPA $\cdot$ Fatty acids $\cdot$ Food quality $\cdot$ Neocalanus

Resale or republication not permitted without written consent of the publisher

\section{INTRODUCTION}

Phytoplankton and other protists vary widely in their composition and nutritional content, causing the quality of copepod diets to vary significantly in the oceans (Jonasdottir et al. 2005, Klein-Breteler et al. 2005). Understanding the extent of natural variability in food quality is important because poor food quality can affect the growth, production and reproduction of cope- pods and fish (e.g. Müller-Navarra et al. 2000, St. John et al. 2001, Arendt et al. 2005). In recent years the use of fatty acid trophic tracers has greatly enhanced our ability to characterize natural variability in the quality of food available for copepods. Marine copepods are incapable of synthesizing the majority of fatty acids required for growth and reproduction and, as such, need to acquire them from their diet (Bell et al. 2007). Phytoplankton produce taxon-specific fatty acids, 
which are retained in their zooplankton predators and can be used as qualitative tracers of dietary source (Dalsgaard et al. 2003). Diatoms, for example, are characterized by high concentrations of eicosapentaeonic acid (EPA, 20:5n-3), 16:1n-7 and by the presence of polyunsaturated fatty acids (PUFA) containing 16 carbon chains (16PUFA), whereas dinoflagellates are characterized by high concentrations of the essential PUFA docosahexaeonic acid (DHA, 22:6n-3) and PUFA containing 18 carbons (18PUFA, specifically, 18:4n-3) (Thompson et al. 1992, Viso \& Marty 1993, Graeve et al. 1994, 2005, Stevens et al. 2004a). Essential PUFAs such as DHA and EPA are important for the physiology of marine copepods and have been shown to affect the efficiency by which energy is transferred in food webs (Müller-Navarra et al. 2000, St. John et al. 2001). Other examples of fatty acid trophic markers of phytoplankton, microzooplankton, bacteria and calanoid copepods are provided in Table 1.

The use of fatty acid trophic markers in calanoid copepods has been verified in the laboratory and the field, and has succeeded in establishing trophic relations among and within different species of copepods and across large spatial gradients (e.g. Graeve et al. 1994, 2005, Stevens et al. 2004b). Most studies have focused on either spatial trends within a single region or short-term temporal trends, usually on the scale of a single year (e.g. Stevens et al. 2004b, Lischka \& Hagen 2007). In contrast, interannual variability in dietary quality remains poorly documented, but has been suggested to play a role in controlling population dynamics of marine organisms on long time scales (Kattner et al. 1994, Litzow et al. 2006). Here, we use fatty acid trophic markers to characterize interannual variability in the diet of an important calanoid copepod from a productive and highly variable coastal ecosystem over a period of $6 \mathrm{yr}$.

The Strait of Georgia (SoG) is a highly productive coastal ecosystem on the west coast of Canada. Biological production in the SoG is highly seasonal, with peak biomass and production of zooplankton and phytoplankton occurring in the spring (Harrison et al. 1983). The spring mezozooplankton biomass is dominated by Neocalanus plumchrus, a large, lipid-storing calanoid copepod (Harrison et al. 1983). Copepodites of $N$. plumchrus appear early in the spring bloom and, while feeding, molt through 5 copepodite stages (CI-CV) becoming progressively larger and accumulating large lipid stores (Evanson et al. 2000). Later in the spring, when it reaches stage $\mathrm{CV}, N$. plumchrus descends to a depth of $\sim 400 \mathrm{~m}$ where it overwinters until it molts into the adult stages in the winter (Campbell et al. 2004). Fatty acid signatures of overwintering Neocalanus spp. have been used to infer the quality of the diet they have experienced during the previous spring (Evanson et al. 2000, Saito \& Kotani 2000).
Although the composition of the spring phytoplankton bloom in the SoG varies significantly from year to year, the extent to which variability in dietary quality affects Neocalanus plumchrus has never been studied (Stockner et al. 1979). During the spring bloom, the SoG phytoplankton community progresses from a flagellate-dominated winter community to a diatomdominated spring community, and the diet available to $N$. plumchrus is usually composed of a mixture of both types of phytoplankton (Harrison et al. 1983). N. plumchrus copepodites have been shown to achieve their optimal body ration while feeding on a mixture of large diatoms and flagellates, rather than a diet composed exclusively of either item (Parsons et al. 1969). Variation in the relative composition of diatoms and dinoflagellates in the diet have been shown to affect the retention of the essential PUFAs EPA and DHA in copepods (Graeve et al. 1994, Stevens et al. 2004a).

The goal of the present study was to characterize the range of interannual variability in the diet of Neocalanus plumchrus and to link it to environmental parameters (phytoplankton composition) and population dynamics (patterns in copepod abundance). We tested whether the relative abundance of the essential fatty acids EPA and DHA varied with changes in phytoplankton composition of the lipid profiles of diapausing and actively feeding copepods. We also considered 2 yr of fatty acid data from $N$. plumchrus and its congener N. cristatus at Ocean Station $\mathrm{P}\left(\mathrm{OSP}, 50^{\circ} \mathrm{N}\right.$ $\left.145^{\circ} \mathrm{W}\right)$ in the northeast subarctic Pacific Ocean to more clearly characterize regional geographic variability in the diet of Neocalanus spp. The present study represents the longest time series of fatty acid composition in calanoid copepods reported to date.

\section{MATERIALS AND METHODS}

Field methods. Interannual patterns in copepod fatty acids and phytoplankton composition: Neocalanus plumchrus from the SoG were collected from a single station located in the deepest pocket in the SoG, at $49^{\circ} \mathrm{N}, 123^{\circ} \mathrm{W}$ (Fig. 1). Sampling was conducted in May (2003-2006) or in the fall (2001-2002) of each year when the $N$. plumchrus SoG community was composed almost entirely of overwintering stage CV copepods. These copepods feed only in the spring and spend the rest of year in a state of diapause, subsisting on their lipid reserves. Copepods collected during the autumn were not expected to have different lipid profiles than those collected in the summer because they have not ingested anything new, and because only a small fraction of wax esters is consumed between those months and fatty acids are consumed in proportion to each other (Evanson et al. 2000, Campbell et al. 2004). For 

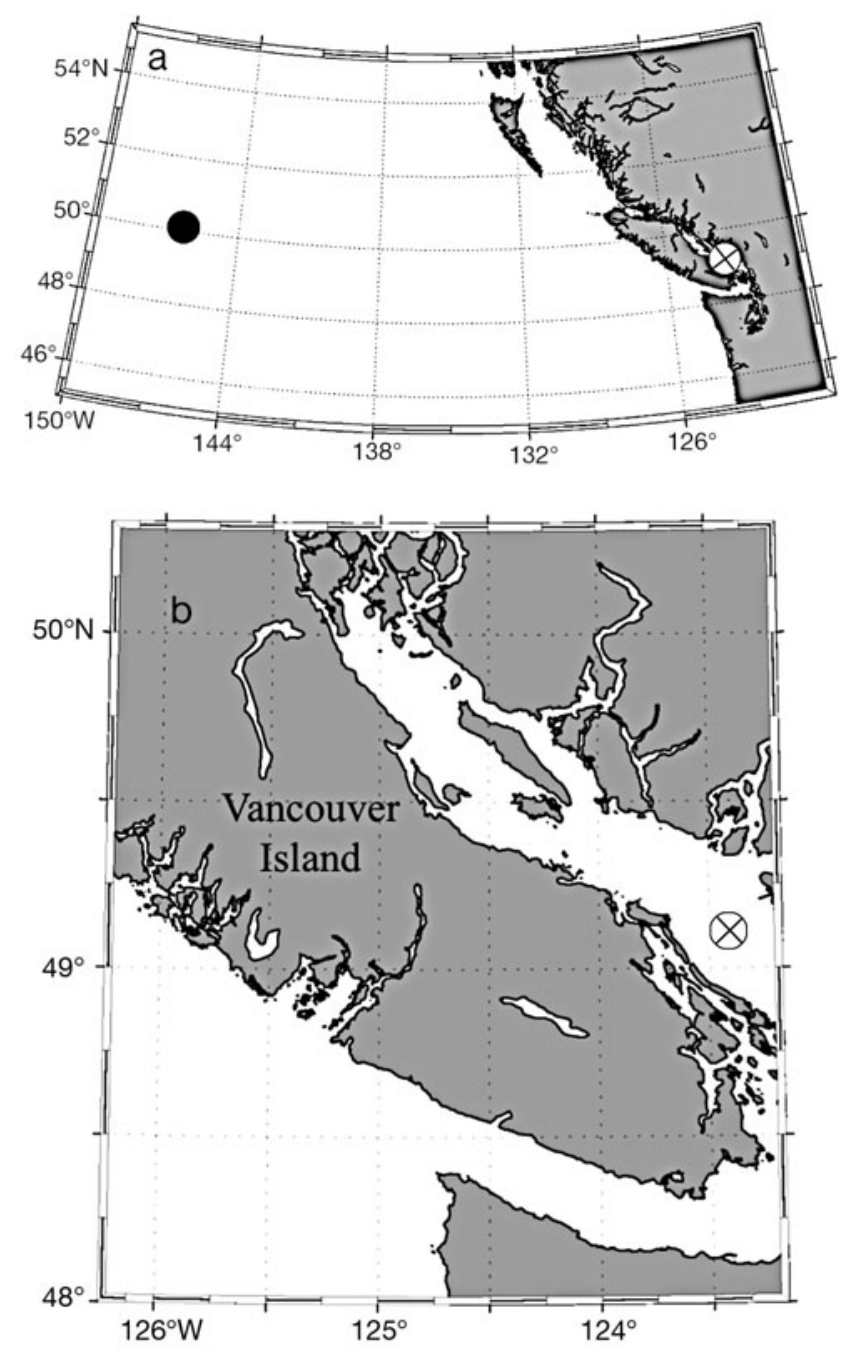

Fig. 1. (a) Sampling sites in the Strait of Georgia $(\otimes$, Station $\left.\mathrm{S} 4-1,49^{\circ} \mathrm{N} 123^{\circ} \mathrm{W}\right)$ and the northeast subarctic Pacific (•, Ocean Station $\mathrm{P}, 50^{\circ} \mathrm{N} 145^{\circ} \mathrm{W}$ ). (b) Close-up of Strait of Georgia location $(\otimes)$

fatty acid analysis, N. plumchrus were sorted from 0 to $400 \mathrm{~m}$ vertical net tows collected with a SCOR net $\left(0.57 \mathrm{~m}\right.$ diameter, $236 \mu \mathrm{m}$ mesh, towed at $\left.0.5 \mathrm{~m} \mathrm{~s}^{-1}\right)$. Each replicate contained $\sim 10$ to 30 copepods, and the number of replicates for a given date ranged from 1 to 7 , depending on the availability of copepods. Sorted samples were stored in cryovials at $-80^{\circ} \mathrm{C}$ until analysis. Samples from OSP (N. plumchrus and N. cristatus) were collected from 0 to $1000 \mathrm{~m}$ in September of 2001 and 2005 using the same sorting and storage procedures.

Phytoplankton community composition and Neocalanus plumchrus abundance data from the Strait of Georgia Ecosystem Modelling Study (STRATOGEM, www.stratogem.ubc.ca) were used to contextualize the fatty acid profiles of $N$. plumchrus. The STRATOGEM project ran from April 2002 to June 2005, and included monthly to bimonthly sampling from several stations in the SoG (R. Pawlowicz et al. unpubl. data). Phytoplankton samples were collected at the chlorophyll maximum $(\sim 5 \mathrm{~m})$ during the spring blooms of 20032005 and once in the spring bloom of 2002 (Sastri \& Dower 2009). Samples were preserved in Lugol's, identified under an inverted compound microscope and converted to biomass (Sournia 1978). Phytoplankton were divided into 4 taxonomic groups: diatoms, dinoflagellates, flagellates (containing cryptophytes, euglenoids and all other flagellates) and photosynthetic ciliates Mesodinium rubrum. For each cruise, the Shannon-Weiner diversity index was calculated as $H^{\prime}=\Sigma p_{i} \ln p_{i}$, where $p_{i}$ is the proportion of each taxonomic group as a total of the biomass (Zar 1984). Unfortunately, phytoplankton composition data were unavailable from 2001 or 2006.

As part of STRATOGEM, the SoG Neocalanus plumchrus population was sampled at least monthly to track seasonal and interannual trends in abundance (expressed in copepods $\mathrm{m}^{-2}$ ). Here we report $N$. plumchrus abundance data which correspond to the dates from which fatty acids were analyzed. N. plumchrus abundance data from 2001 to 2002 were taken from Campbell et al. (2004). Samples were collected using the same net as previously described and preserved in $5 \%$ buffered formalin. Samples from 2006 were collected from the same station on ships of opportunity.

Fatty acid dynamics during the spring bloom of 2005: To assess how diatoms and flagellate fatty acid markers in Neocalanus plumchrus varied in relation to phytoplankton composition during active copepod development, sampling of SoG $N$. plumchrus abundance, fatty acid profiles of copepods and phytoplankton community composition was conducted over 5 cruises during the spring bloom of 2005 (over 80 d), in conjunction with the STRATOGEM program. Copepod fatty acid samples were processed as previously described, but with a larger number of $N$. plumchrus per replicate ( 30 to 60 copepods per replicate) to account for the low body mass of juvenile stages. Phytoplankton composition was measured as previously described.

Laboratory methods. In the lab, animals were freezedried $\left(<40^{\circ} \mathrm{C}\right.$ for $\left.48 \mathrm{~h}\right)$, weighed and placed in $2 \mathrm{ml}$ HPLC-grade chloroform. The samples were flushed with nitrogen gas, sealed with Teflon ${ }^{\circledR}$-lined caps, wrapped in Teflon ${ }^{\circledR}$ tape and stored at $-80^{\circ} \mathrm{C}$ until extraction.

Fatty acid extractions were based on the protocols of Parrish (1999) and Kainz et al. (2004). The samples were sonicated and vortexed 3 times in a 4:2:1 chloroform:methanol:water mixture. The extraction took place on ice and under $\mathrm{N}_{2}$ gas to limit possible sample degradation. The organic layers were pooled in a single tube, and the extracts capped in under $\mathrm{N}_{2}$ gas, 
sealed and stored at $-80^{\circ} \mathrm{C}$ to prevent degradation. Fatty acids were analyzed as methyl esters prepared by trans-esterfying the lipid extract in $14 \%$ BF3$\mathrm{CH} 3 \mathrm{OH}$ at $85^{\circ} \mathrm{C}$ for $1 \mathrm{~h}$ (Kainz et al. 2004).

Esterified fatty acids were analyzed using a gas chromatograph (Varian CP-3800) equipped with a flame ionization detector, and a Suppelco 2560 capillary column $(100 \mathrm{~m}, 0.25 \mathrm{~mm}$ inner diameter, $0.2 \mu \mathrm{m}$ film thickness). Unmethylated tricosonic acid (23:00) was used as an internal standard to check the combined efficacy of the procedure. Fatty acid methyl esters were identified by comparing retention times against those of a commercial standard (37-component FAME mix, Supelco 47885-U). Fatty acids not included in this standard were verified using mass spectra (Varian $2000 \mathrm{GC} /$ mass spectrometer) following Ackman (1991). The extraction and methylation efficiency was $>90 \%$, and the coefficient of variation among multiple injections of the same standard was $<5 \%$. All fatty acid data were reported as \% total fatty acids. The trophic and dietary tracers used in the present study are summarized in Table 1.

Statistical analysis. Both nonparametric multivariate and parametric univariate analyses were used to explore underlying structures in the data and to test the significance of differences in fatty acid markers. Nonparametric multivariate analyses were performed using PRIMER (version 5) following Clarke (1993). All statistical analyses were performed on fatty acid data expressed as \% total fatty acids. A Bray-Curtis dissimilarity matrix was constructed using raw, untransformed fatty acid data (expressed in \% total fatty acids) (Bray \& Curtis 1957). The resultant groupings were visualized via multi-dimensional scaling (MDS) ordi- nation and average neighbour clustering using rank similarities. Stress values $<0.20$ were considered robust following the recommendation of Clarke (1993). Analysis of similarities (ANOSIM) was performed to test the statistical significance of groupings, followed by similarity percentage (SIMPER) analysis to assess the contributions of individual fatty acids to the observed clustering pattern. Subsequently, 1-way ANOVA was performed on arcsine-transformed percentage data (tested for normality and equal variance) to test the significance of those fatty acids trophic markers that SIMPER showed to be important. A Tukey-Kramer post hoc analysis was applied to compare means when ANOVAs were significant. Samples from 2001 to 2002 were excluded from the ANOVA because they consisted of only single values without replicates. OSP animals from both 2001 and 2005 were combined for the ANOVA because they were not significantly different. Univariate analyses were performed using JMP (version 6) following Zar (1984).

\section{RESULTS}

\section{Patterns in Neocalanus plumchrus abundance and phytoplankton composition}

The abundance of SoG Neocalanus plumchrus declined by $\sim 80 \%$, from $>8000$ ind. $\mathrm{m}^{-2}$ in 2001 to $<2000$ ind. $\mathrm{m}^{-2}$ in 2006 (Fig. 2). Diatoms were consistently the most dominant phytoplankton group during the spring bloom, but the composition of the phytoplankton community varied considerably from year to year (Fig. 3a). The concentration of diatoms increased

Table 1. Summary of trophic and dietary fatty acid tracers discussed in the present study

\begin{tabular}{|c|c|c|}
\hline Tracer & Diet & Source \\
\hline $16: 1 n-7$ & Diatoms & Graeve et al. (1994), Viso \& Marty (1993) \\
\hline EPA & Diatoms & Viso \& Marty (1993), Graeve et al. $(1994,2005)$ \\
\hline $16 P U F A^{a}$ & Diatoms & Thompson et al. (1992), Graeve et al. $(1994,2005)$ \\
\hline DHA & Dinoflagellates & Viso \& Marty (1993) \\
\hline $18 P U F A^{b}$ & Flagellates & Thompson et al. (1992), Viso \& Marty (1993) \\
\hline DHA/EPA & Flagellates to diatom, carnivory & Budge \& Parrish (1998) \\
\hline 16PUFA/18PUFA & Herbivory, diatoms to flagellates & Mayzaud et al. (1989), Budge \& Parrish (1998) \\
\hline $18: 2 n-6$ & Terrestrial plants/green algae & Dalsgaard et al. (2003) \\
\hline $15: 0+17: 0^{\mathrm{c}}$ & Bacteria & Kaneda (1991) \\
\hline $18: 1 n-9 / 18: 1 n-7$ & Bacteria and omnivory & Stevens et al. $(2004 a, b)$ \\
\hline 20-22MUFA ${ }^{\mathrm{d}}$ & Wax ester synthesis & Sargent \& Whittle (1981) \\
\hline 22MUFA/20MUFA ${ }^{\mathrm{e}}$ & Calorific value & Scott et al. (2002) \\
\hline \multicolumn{3}{|c|}{$\begin{array}{l}\text { ancludes all PUFA containing } 16 \text { carbon atoms } \\
\text { bIncludes all PUFA containing } 18 \text { carbon atoms } \\
\text { cIncludes iso and anti-iso branched chains containing } 15-17 \text { carbon atoms } \\
\text { d Includes all monounsaturated fatty acids containing } 20 \text { or } 22 \text { carbon atoms }(20: 1 \mathrm{n}-9,20: 1 \mathrm{n}-11,22: 1 \mathrm{n}-9 \text { and } 22: 1 \mathrm{n}-11) \\
\text { eSum of } 22: 1 \mathrm{n}-9 \text { and } 22: 1 \mathrm{n}-11 \text { over the sum of } 20: 1 \mathrm{n}-9 \text { and } 20: 1 \mathrm{n}-11\end{array}$} \\
\hline
\end{tabular}




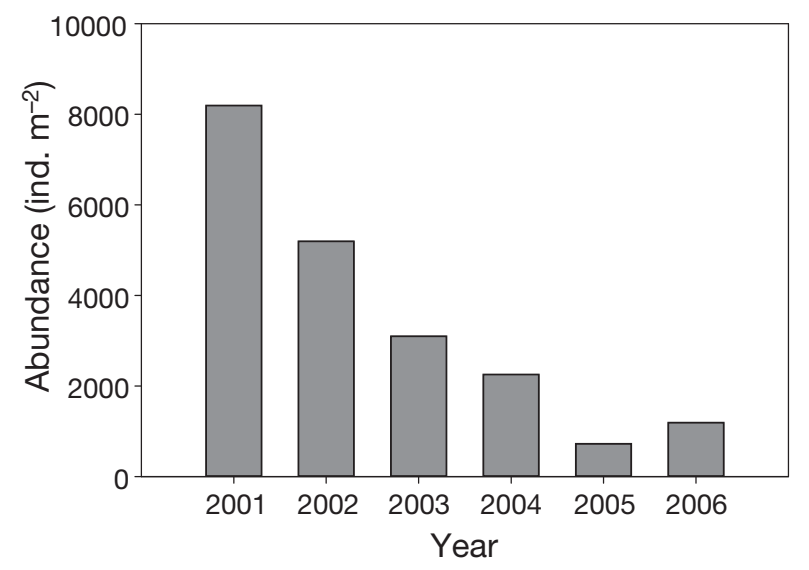

Fig. 2. Neocalanus plumchrus. Abundance of diapausing copepods $\mathrm{m}^{-2}$ from 0 to $400 \mathrm{~m}$ depth in the Strait of Georgia between 2001 and 2006. Data from 2001-2002 are from October, 2003-2006 data are from May
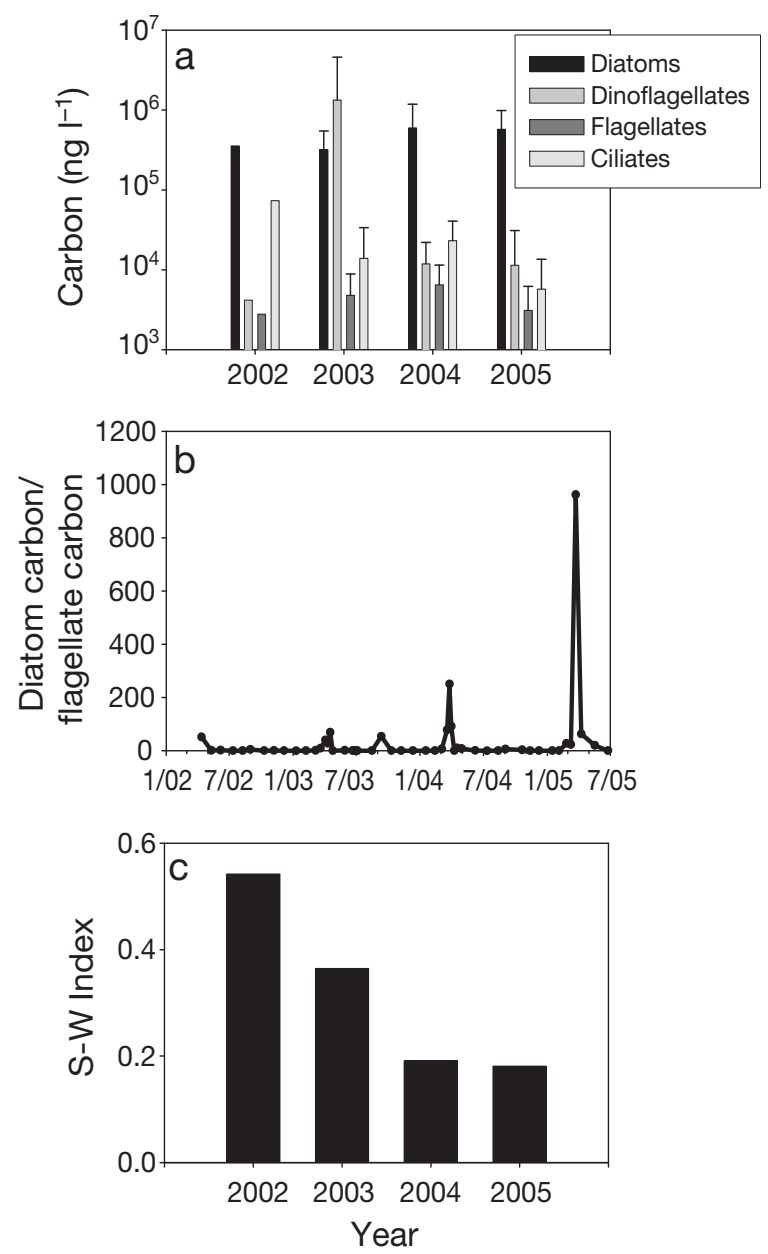

Fig. 3. Spring phytoplankton blooms in $2002(n=1), 2003(n=$ 8), $2004(\mathrm{n}=8)$ and $2005(\mathrm{n}=4)$. (a) Composition; (b) proportion of diatoms to flagellates at the peak of the phytoplankton from each year; (c) Shannon-Wiener index $\left(\mathrm{H}^{\prime}\right)$ of group diversity averaged over spring blooms considerably between 2002 and 2005, causing the maximum proportion of diatom carbon to total flagellate carbon to increase progressively, from $200 \times$ in the spring blooms of $2002-2003$ to more than $800 \times$ in the spring bloom of 2005 (Fig. 3b). As a result, the average Shannon-Wiener index during the time when N. plumchrus was actively feeding was lower in 2004-2005 $(\sim 0.20)$ than in 2002-2003 ( 0.55), indicating that the developing $N$. plumchrus copepodites encountered a more homogeneous, diatom-dominated diet in 2004-2005 than in 2002-2003 (Fig. 3c).

\section{Fatty acids}

Fatty acid profiles of Neocalanus spp. from the SoG and OSP were dominated by the saturated fatty acids 14:0 and 16:0 and the essential PUFAs EPA and DHA. MDS ordination (overlaid with cluster analysis) separated the data into 3 statistically different groups (Fig. 4, Table 2). Cluster 1 included N. plumchrus and $N$. cristatus from OSP, plus the SoG $N$. plumchrus from 2001. Cluster 2 contained SoG N. plumchrus from 2002 to 2004, while Cluster 3 encompassed SoG N. plumchrus from 2005 to 2006. Clusters 1 and 3 were the most separated (Global $\mathrm{R}=0.771$ ), while Clusters 1 \& 2 and $2 \& 3$ displayed a higher degree of overlap (Global $\mathrm{R}=0.660$ and 0.595 , respectively). Clusters 2 and 3 were separated from Cluster 1 primarily on the basis of the proportions of 20-22MUFA and 18PUFA (which were higher in oceanic than in coastal copepods) and

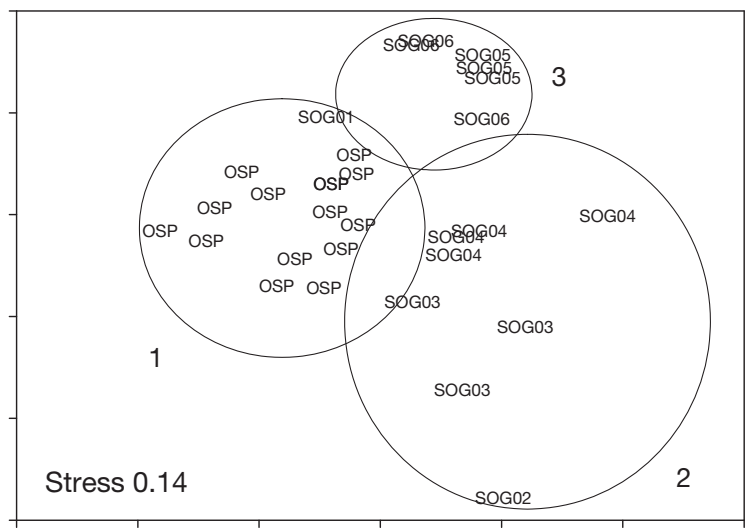

Fig. 4. Multidimensional scaling ordination of a Bray-Curtis dissimilarity matrix calculated from raw, untransformed proportional fatty acid data. The degree of stress (0.14) is within the range of values recommended by Clarke (1993) for robust groupings. Copepods from the Strait of Georgia are indicated as SoG followed by year of sampling (e.g. SOG01 is Neocalanus plumchrus from 2001) and Ocean Station P copepods are indicated as OSP regardless of species. Circles represent groupings revealed by rank-based average neighbour clustering performed on the same matrix. Significant differences and degree of overlap are indicated in Table 2 
Table 2. Analysis of similarities (ANOSIM) between the 3 clusters discovered with multidimensional scaling analysis and clustering as shown in Fig. 4. Each value is represented as the Global R statistic (p-value). Cluster 1 contains all oceanic Neocalanus spp. and N. plumchrus from the Strait of Georgia from 2001. Cluster 2 contains all Strait of Georgia copepods from 2002-2004. Cluster 3 contains Strait of Georgia copepods from 2005-2006

\begin{tabular}{|cccc|}
\hline & Cluster 1 & Cluster 2 & Cluster 3 \\
\hline Cluster 1 & & $0.66(0.001)$ & $0.771(0.001)$ \\
Cluster 2 & $0.66(0.001)$ & & $0.595(0.002)$ \\
Cluster 3 & $0.771(0.001)$ & $0.595(0.002)$ & \\
\hline
\end{tabular}

by 16PUFA and EPA (which displayed the opposite trend, Table 3). Cluster 3 was further separated from Cluster 2 by having high proportions of diatom markers (EPA and 16PUFA, Table 3). 16PUFA were composed predominantly of $16: 4 \mathrm{n}-1$ while concentrations of $16: 4 n-3$ were very low (data not shown). On the other hand, 18PUFA were composed predominantly of $18: 4 n-3$, while concentrations of $18: 3 n-3$ and $18: 3 n-6$ were low and 18:5n-3 was undetected in any of the samples (data not shown).

Diatom markers (EPA, 16:1n-7 and 16PUFA) were highest in SoG Neocalanus plumchrus from 2005 to 2006 and lowest in oceanic copepods (Table 4). Flagellate markers (DHA and 18PUFA) were high in oceanic samples and low in the SoG, with the exception of 2003 (Table 4). The green algal/terrestrial detritus marker 18:2n-6 was higher in 2004-2005 than in any other year in SoG, and was low in OSP samples (Table 4). The ratio of 16PUFA to 18PUFA (indicating the relative proportion of diatoms to flagellates in the diet) was highest in 2005 and 2006, and lowest in oceanic copepods, while the opposite was generally true for DHA/EPA ratios (which indicate the relative proportions of dinoflagellates to diatoms in the diet) (Table 4). Bacterial markers were higher in oceanic copepods than in coastal copepods, with the exception of 2004, and there were no significant differences in the omnivory index 18:1n-9/18:1n-7 among any of the samples (Table 4). This index has been found to be elevated in carnivorous copepods and those feeding on microzooplankton (Stevens et al. 2004a, El-Sabaawi et al. 2009). 2022MUFA were significantly higher in oceanic samples than in coastal samples (where there were also no significant differences between years), and the ratio of 22MUFA/20MUFA was highest in $N$. cristatus.

\section{The spring bloom of 2005}

During the spring bloom of 2005 a major collapse in the population of Neocalanus plumchrus was observed
Table 3. Similarity percent (SIMPER) analysis used to assess the contribution of individual fatty acids to the 3 clusters discovered by multidimensional scaling analysis and clustering as shown in Fig. 4. All values are expressed in \% fatty acid. Avg. \% comp: average composition of the tracer present in each cluster; Cumul.\%: cumulative dissimilarity explained by the tracer

\begin{tabular}{|c|c|c|c|}
\hline Fatty acid & ivg. \% comp & Avg. \% comp & Cumul. \% \\
\hline \multicolumn{4}{|c|}{ Clusters 1 and 2 (average dissimilarity $26.75 \%$ ) } \\
\hline & Cluster 1 & Cluster 2 & \\
\hline 20-22MUFA & 13.84 & 4.47 & 21.05 \\
\hline 18PUFA & 9.92 & 3.91 & 34.61 \\
\hline $14: 0$ & 19.16 & 20.86 & 47.22 \\
\hline $16: 0$ & 12.48 & 16.11 & 59.34 \\
\hline $18: 2 n-6$ & 1.64 & 6.15 & 69.41 \\
\hline 16PUFA & 2.73 & 4.84 & 76.95 \\
\hline EPA & 11.4 & 10.3 & 84.18 \\
\hline DHA & 7.21 & 6.86 & 89.83 \\
\hline $18: 1 n-9 / 18: 1 n-7$ & $7 \quad 3.34$ & 4.02 & 93.25 \\
\hline \multicolumn{4}{|c|}{ Clusters 1 and 3 (average dissimilarity $25.92 \%$ ) } \\
\hline & Cluster 1 & Cluster 3 & \\
\hline 16PUFA & 2.73 & 9.57 & 16 \\
\hline 20-22MUFA & 13.84 & 7.82 & 30.57 \\
\hline 18PUFA & 9.92 & 3.59 & 44.27 \\
\hline $14: 0$ & 19.16 & 24.71 & 56.47 \\
\hline $18: 2 n-6$ & 1.64 & 6.11 & 67.86 \\
\hline EPA & 11.4 & 16.3 & 78.55 \\
\hline DHA & 7.21 & 4.13 & 85.22 \\
\hline $15+17$ & 2.68 & 0.71 & 89.46 \\
\hline $18: 1 n-9 / 18: 1 n-7$ & $7 \quad 3.34$ & 1.54 & 93.48 \\
\hline \multicolumn{4}{|c|}{ Clusters 2 and 3 (average dissimilarity $23.00 \%$ ) } \\
\hline & Cluster 2 & Cluster 3 & \\
\hline EPA & 10.3 & 16.3 & 15.5 \\
\hline $14: 0$ & 20.86 & 24.71 & 30.74 \\
\hline $16: 0$ & 16.11 & 12.32 & 44.41 \\
\hline 16PUFA & 4.84 & 9.57 & 56.09 \\
\hline $18: 2 n-6$ & 6.15 & 6.11 & 66 \\
\hline 20-22MUFA & 4.47 & 7.82 & 74.81 \\
\hline DHA & 6.86 & 4.13 & 82.18 \\
\hline $18: 1 n-9 / 18: 1 n-7$ & $7 \quad 4.02$ & 1.54 & 88.5 \\
\hline $16: 1 \mathrm{n}-7$ & 1.88 & 3.41 & 92.3 \\
\hline
\end{tabular}

in late March (between Julian Days 60 and 80), during which the abundance of actively feeding copepods declined from $\sim 35$ to $\sim 4 \mathrm{~m}^{-3}$ (Fig. 5a). This collapse coincided with a spike of diatom production in which diatom carbon was $\sim 1000 \times$ more abundant than flagellate and ciliate carbon (Fig. 5b). During this time the proportion of diatoms in the diet of developing $N$. plumchrus copepodites also increased, as evidenced by a decrease in the DHA/EPA ratio and an increase in the 16PUFA/18PUFA ratio in the copepods. The former was caused by a decrease in the proportions of DHA, while the latter was caused by the preferential accumulation of diatom markers compared to flagellate markers (Fig. 5c-e). 
Table 4. Composition of fatty acid trophic markers in Neocalanus spp. from the Strait of Georgia and Ocean Station P (OSP). Composition expressed in \% total fatty acids; data are mean (SD). Uppercase letter superscripts designate years or organisms that are found to be significantly different by ANOVA performed on arc-transformed data, followed by Tukey-Kramer post hoc analysis $(p<0.05)$. Order of letters corresponds to average level of tracer. Values not followed by letters were not tested using ANOVA. OSPP: N. plumchrus; OSPC: N. cristatus; n: number of samples

\begin{tabular}{|c|c|c|c|c|c|c|c|c|}
\hline Fatty acid tracer & 2001 & 2002 & 2003 & 2004 & 2005 & 2006 & OSPP & OSPC \\
\hline $14: 0$ & 22.9 & 26 & $18.6(1.7)^{\mathrm{BC}}$ & $18.2(3.1)^{\mathrm{BC}}$ & $25.8(1)^{\mathrm{A}}$ & $23.7(0.5)^{\mathrm{AB}}$ & $21.9(2.1)^{\mathrm{AB}}$ & $15.1(4.7)^{\mathrm{C}}$ \\
\hline $16: 0$ & 13.6 & 26.8 & $15.6(4.6)^{\mathrm{A}}$ & $10.2(1.6)^{\mathrm{B}}$ & $11.5(0.2)^{\mathrm{B}}$ & $13.2(0.3)^{\mathrm{B}}$ & $13(1.2)^{\mathrm{B}}$ & $11.6(1.2)^{\mathrm{B}}$ \\
\hline $18: 0$ & 0.9 & 2.8 & $1.6(0.7)$ & $1.3(0.3)$ & $0.7(0)$ & $1.1(0.2)$ & $1.1(0.3)$ & $1(0.4)$ \\
\hline sum $15+17^{a}$ & 1.5 & 1.1 & $1.3(0.6)^{\mathrm{D}}$ & $2.0(1.1)^{\mathrm{BC}}$ & $0.5(0.2)^{\mathrm{D}}$ & $1.0(0.3)^{\mathrm{CD}}$ & $2.2(0.6)^{\mathrm{B}}$ & $3.5(0.7)^{\mathrm{A}}$ \\
\hline $16: 1 n-7$ & 3.1 & 0.8 & $1.5(0.6)^{\mathrm{BC}}$ & $2.2(0.1)^{\mathrm{BC}}$ & $3.6(0.5)^{\mathrm{A}}$ & $3.2(0.3)^{\mathrm{A}}$ & $2.1(0.7)^{\mathrm{C}}$ & $1.8(0.5)^{\mathrm{C}}$ \\
\hline 16 PUFA $^{\mathrm{b}}$ & 4.0 & 2.0 & $4.5(1.7)^{\mathrm{BC}}$ & $6.4(0.8)^{\mathrm{BC}}$ & $10(0.4)^{\mathrm{A}}$ & $9.1(0.8)^{\mathrm{AB}}$ & $3.6(0.4)^{\mathrm{CD}}$ & $1.4(0.5)^{\mathrm{D}}$ \\
\hline EPA & 9.8 & 6.6 & $12.2(2.9)^{\mathrm{A}}$ & $8.6(2.2)^{\mathrm{C}}$ & $15.6(1.5)^{\mathrm{A}}$ & $17(1.5)^{\mathrm{A}}$ & $10.9(2.6)^{\mathrm{BC}}$ & $11.8(2)^{\mathrm{B}}$ \\
\hline 18PUFA ${ }^{\mathrm{c}}$ & 4.9 & 2.4 & $4.7(1.7)^{\mathrm{A}}$ & $2.8(0.9)^{\mathrm{CD}}$ & $4.1(0.8)^{\mathrm{D}}$ & $3.1(0.6)^{\mathrm{D}}$ & $10.6(1.5)^{\mathrm{AB}}$ & $9.8(2.3)^{\mathrm{BC}}$ \\
\hline DHA & 6.5 & 6.9 & $8.6(2.8)^{\mathrm{A}}$ & $5.5(1.4)^{\mathrm{CD}}$ & $3.9(0.6)^{\mathrm{D}}$ & $4.4(0.8)^{\mathrm{D}}$ & $6.7(1.6)^{\mathrm{AB}}$ & $7.9(1.6)^{\mathrm{BC}}$ \\
\hline $18: 1 n-9$ & 2.3 & 2.8 & $3.0(1.6)$ & $4.0(1.1)$ & $0.9(0.2)$ & $1.8(1.8)$ & $1.8(0.3)$ & $1.7(0.2)$ \\
\hline $20: 1 n-9$ & 5.3 & 0.7 & $0.5(0.7)$ & $0.4(0.5)$ & $1.2(0.5)$ & $2.3(1.3)$ & $1.3(0.9)$ & $2.4(1)$ \\
\hline $20: 1 n-11$ & 4.2 & 0.9 & $1.0(1.3)$ & $1.5(0.3)$ & $3.1(0.2)$ & $2.6(2.2)$ & $4.5(3.6)$ & $1.8(1.5)$ \\
\hline $22: 1 n-9$ & 1.4 & 0.6 & $1.6(1.8)$ & $2.5(0.9)$ & $0.1(0)$ & $3.8(3.2)$ & $0.9(2.0)$ & $0.9(0.8)$ \\
\hline $22: 1 n-11$ & 7.9 & 2.2 & $1.1(1.5)$ & $0(0.1)$ & $2.6(0.3)$ & $0(0)$ & $4.3(2.4)$ & $11.7(5.1)$ \\
\hline $18: 2 n-6$ & 0.8 & 3.8 & $5.5(0.7)^{\mathrm{C}}$ & $7.4(1.4)^{\mathrm{BC}}$ & $9.8(0.4)^{\mathrm{AB}}$ & $2.5(3.6)^{\mathrm{D}}$ & $1.8(0.2)^{\mathrm{D}}$ & $1.5(0.2)^{\mathrm{D}}$ \\
\hline 16PUFA/18PUFA & 0.8 & 0.8 & $1.0(0.2)$ & $2.5(0.7)$ & $2.5(0.6)$ & $3.0(0.6)$ & $0.5(0.5)$ & $0.2(0.1)$ \\
\hline DHA/EPA & 0.7 & 1.1 & $0.7(0.1)^{\mathrm{A}}$ & $0.6(0.1)^{\mathrm{A}}$ & $0.3(0.1)^{\mathrm{B}}$ & $0.3(0.1)^{\mathrm{B}}$ & $0.6(0.1)^{\mathrm{A}}$ & $0.7(0.1)^{\mathrm{A}}$ \\
\hline $18: 1 n-9 / 18: 1 n-7$ & 3.2 & 6.8 & $3.6(0.4)^{\mathrm{A}}$ & $3.9(2.3)^{\mathrm{A}}$ & $1.7(0.2)^{\mathrm{A}}$ & $1.4(1.3)^{\mathrm{A}}$ & $3.3(1.1)^{\mathrm{A}}$ & $3.4(0.9)^{\mathrm{A}}$ \\
\hline 20-22 MUFA & 18.7 & 4.3 & $4.3(1.9)^{\mathrm{C}}$ & $4.4(0.8)^{\mathrm{C}}$ & $7.0(0.7)^{\mathrm{C}}$ & $8.7(2.8)^{\mathrm{BC}}$ & $11(3.7)^{\mathrm{B}}$ & $16.8(5.6)^{\mathrm{A}}$ \\
\hline 22MUFA/20MUFA & 1.0 & 1.7 & $1.8(0.2)^{\mathrm{B}}$ & $1.3(0.6)^{\mathrm{B}}$ & $0.6(0.1)^{\mathrm{B}}$ & $0.9(0.8)^{\mathrm{B}}$ & $1(0.4)^{\mathrm{B}}$ & $3.8(1.3)^{\mathrm{A}}$ \\
\hline $\mathrm{n}$ & 1 & 1 & 3 & 4 & 3 & 3 & 7 & 7 \\
\hline \multicolumn{9}{|c|}{$\begin{array}{l}\text { ancludes iso and anti-iso branched chains containing } 15 \text { or } 17 \text { carbon atoms } \\
\text { 'Includes all PUFA containing } 16 \text { carbon atoms } \\
\text { 'Includes all PUFA containing } 18 \text { carbon atoms }\end{array}$} \\
\hline
\end{tabular}

\section{DISCUSSION}

\section{General findings and geographic variability}

Our results show significant spatiotemporal variability in the fatty acid composition of Neocalanus spp. The SoG and OSP represent 2 very different feeding environments; the SoG is a highly productive, diatombased system while OSP is a high-nutrient, low-chlorophyll region where iron limits the production of large diatoms and the phytoplankton is composed primarily of small flagellates, cyanobacteria and small diatoms (Harrison et al. 1983, 2004). Grazing experiments have shown that Neocalanus spp. feed primarily on ciliates at OSP, with only a minor contribution from phytoplankton (Dagg 1993). Our fatty acid data support these observations: $N$. plumchrus from the SoG is primarily herbivorous, with high proportions of diatombased fatty acid markers, whereas animals from OSP contain much higher proportions of flagellate and bacterial markers, suggesting omnivorous feeding. Low ratios of $18: 1 n-9 / 18: 1 n-7$ in the lipid of Neocalanus spp., regardless of their origin, suggests that carnivory is not an important feeding habit for this genus (Hagen et al. 1995). Our fatty acid profiles from coastal $N$. plumchrus are in agreement with the findings of Lee (1974), the only other report of complete fatty acid profiles isolated from whole copepods of this genus.

Wax ester synthesis is evidenced by the presence of 20-22MUFA, which are synthesized de novo and can be used as a proxy for wax ester concentrations when combined with their corresponding fatty alcohols (Sargent \& Whittle 1981, Kattner \& Hagen 1995, Saito \& Kotani 2000). The relative proportion of these MUFAs is generally higher in oceanic than in coastal Neocalanus spp., and within the range of proportions reported from the wax esters of other Neocalanus spp. (Lee et al. 2006). Thus, oceanic Neocalanus spp. are higher in calorific content than their coastal congeners, which in turn suggests that they are more adapted to low food concentrations (Scott et al. 2002). Longerchained MUFAs have been shown to contain a higher calorific content than short-chained MUFAs; $N$. cristatus from OSP displays the highest proportion of 22MUFA to 20MUFA indicating that it has a higher calorific value than N. plumchrus at OSP (Scott et al. 2002). Though there are no clear interannual patterns in 20-22MUFA in the SoG, there was a higher contribution of longer-chained MUFA in 2003-2004 compared to 2005-2006 (Table 3), indicating that copepods 

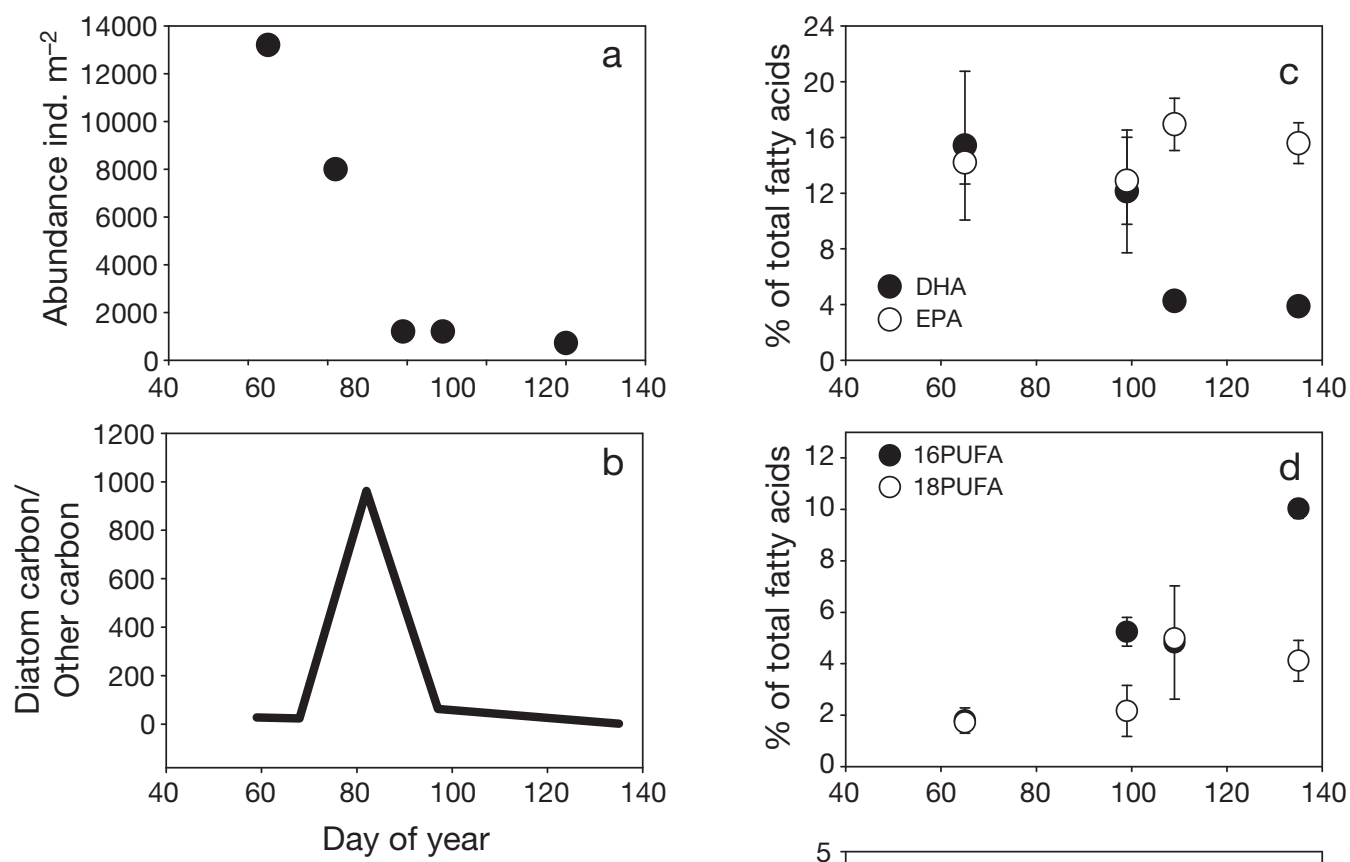

Fig. 5. Neocalanus plumchrus. (a) Collapse in the abundance of $N$. plumchrus in the Strait of Georgia during the spring bloom of 2005 coincides with (b) a high pulse of diatom carbon over other phytoplankton carbon and an increase in contribution of diatoms to the diet as denoted by $(\mathrm{c}-\mathrm{e})$ increasing diatom fatty acids in the lipids of $N$. plumchrus

from 2005-2006 contained more calorific content. This is consistent with values in copepods living under poor food conditions.

\section{Interannual variation in the diet of Neocalanus plumchrus from the SoG}

Over the course of the present study, the abundance of Neocalanus plumchrus in the SoG declined significantly, and a collapse of $N$. plumchrus occurred in spring bloom of 2005 while the developing copepodites stages were feeding (Figs. $2 \& 5$ a). Recent findings suggest that the 2005 collapse of $N$. plumchrus in the SoG coincided with the failure of the developing CII copepodites to molt to CIII, while copepods that made it through this crash continued to develop normally (Sastri \& Dower 2009). Total chlorophyll concentrations in 2005-2006 were not significantly different than in previous years, suggesting that the collapse of $N$. plumchrus did not occur because of food limitation per se (R. Pawlowicz et al. unpubl. data). It is also

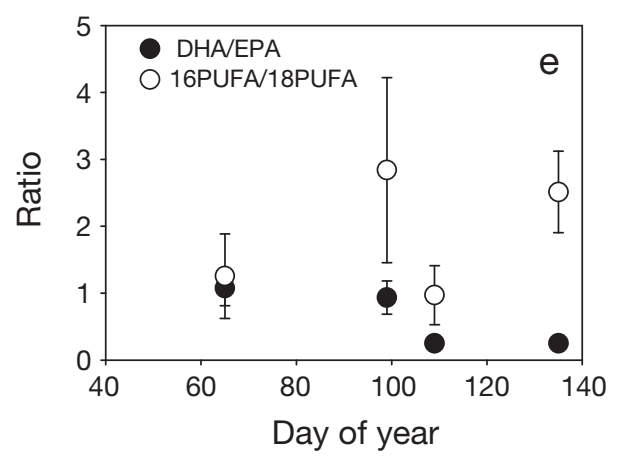

unlikely that the decline in N. plumchrus biomass was the result of increasing predation pressure. Between 2001 and 2005, stocks of major predators in the area (e.g. salmon, herring, hake and birds) did not increase appreciably (DFO 2006), and potential macrozooplankton predators, such as chaetognaths and gelatinous zooplankton, declined (R. El-Sabaawi unpubl. data). The year 2005 is now widely recognized as having been an unusual year in the northeast Pacific: the SoG experienced unusually warm deep water temperatures (though surface temperatures were not warmer than in previous years), and low zooplankton biomass anomalies were observed all the way from Oregon to the west coast of Vancouver Island (Mackas et al. 2006, Masson \& Cummins 2007).

Between 2001 and 2006, the diet of Neocalanus plumchrus in the SoG shifted from OSP-like omnivory (in 2001) to moderate herbivory (between 2002 and 2004), and finally, to intense herbivory dominated by diatom markers (2005-2006, Fig. 4). The increasing proportion of diatoms over flagellates in the diet of $N$. plumchrus in the SoG was signified by the increase of 
the 16PUFA/18PUFA ratio and a decrease in the DHA/EPA ratio, both corresponding to increasing ratios of diatoms to flagellates in the water column. The flagellate marker 18PUFA did not show any significant trend with time in the SoG, indicating that similar total concentrations of flagellates were consumed in each year. However, DHA was low in 2004-2006, suggesting that even though flagellates had been consumed, they were likely not as rich in essential fatty acids as in previous years (Table 4). The high proportion of $18: 2 n-6$ in 2004-2005 relative to other years indicates that animals were supplementing their diet with green algae or terrestrial detritus. Therefore, between 2001 and 2006, not only did the contribution of diatoms in the diets of $N$. plumchrus increase, but the contribution of dinoflagellates decreased in favor of green algae. These patterns correlate more or less with patterns of phytoplankton composition (Fig. 3), though it is important to note that the phytoplankton composition data reported here represent a few sparse sampling points over the spring bloom, which may vary on short time scales. In general, there were no differences in total lipids per copepod observed over the length of the present study (R. El-Sabaawi unpubl. data), and Campbell et al. (2004) observed no significant interannual variability in the concentrations of storage lipids between diapausing animals from 2001 to 2003 .

The highest values of 16PUFA/18PUFA and the lowest values of DHA/EPA occurred in 2005 and 2006, years when Neocalanus plumchrus biomass in the SoG was at its lowest. Interestingly, this is not the first incident in which low $N$. plumchrus biomass coincided with low DHA/EPA ratios in the SoG. The fatty acids of diapausing $N$. plumchrus were measured during a similar decline which occurred in 1996-1997 (Bornhold 2000, Evanson et al. 2000). In 1996, a good year in terms of $N$. plumchrus biomass, the DHA/EPA ratio was $\sim 1.2$, comparable to our values from 2002. In 1997 , a poor year for biomass, the DHA/EPA ratio was $\sim 0.3$, comparable to our values from 2005 to 2006. Regression analysis of $N$. plumchrus abundance on DHA/EPA ratios using all the data gathered in the present study plus data from Evanson et al. (2000) and Bornhold (2000) shows a strong relationship between those 2 parameters $\left(R^{2}=0.6, p<0.001\right.$, Fig. 6$)$, indicating that a decline in the survival of $N$. plumchrus is linked to an imbalance of DHA to EPA availability or retention.

The idea of an optimal ratio of dietary DHA/EPA is already well established in the aquaculture, zooplankton and fisheries literature (Arendt et al. 2005, Jonasdottir et al. 2005). The physiological basis for this is unclear, but DHA and EPA have been shown to be required for different physiological processes in shrimp, where DHA is required for molting and EPA is required for

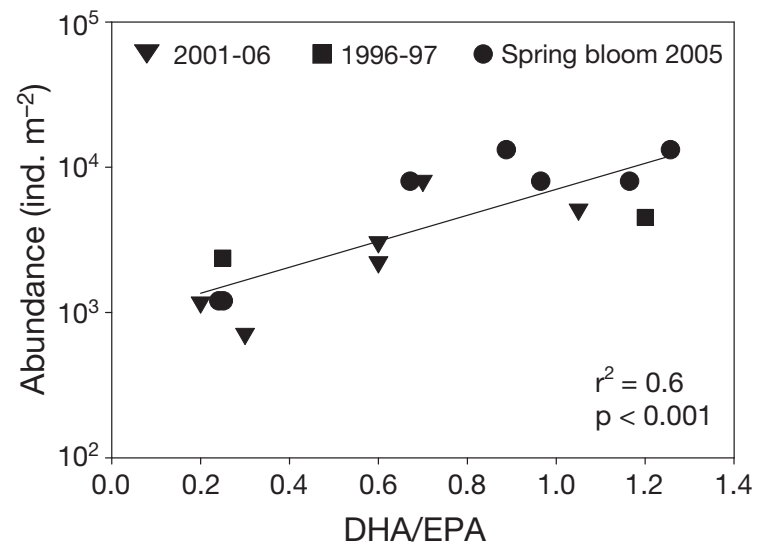

Fig. 6. Neocalanus plumchrus. Relationship between $N$. plumchrus abundance (copepods $\mathrm{m}^{-2}$ ) and the ratio of DHA/EPA in ( $\mathbf{\nabla})$ diapausing copepods from 2001-2006, (•) actively feeding copepods from the spring bloom of 2005 and (匹) diapausing copepods from 1996-1997 (Bornhold 2000, Evanson et al. 2000). DHA and EPA are essential fatty acids required for copepod growth and reproduction. Optimal dietary DHA/EPA have been shown to be required for the growth and reproduction of copepods, larval fishes and clams

maintaining general physiological function (Kobayashi et al. 2000). The correlation between molting failure in Neocalanus plumchrus and low DHA/EPA ratios in the copepods during the spring bloom of 2005 supports these observations. However, the fact that N. plumchrus copepodites that survived the crash continued to molt and develop normally despite low DHA/EPA ratios suggests that the somatic requirement of DHA and EPA differs among stages, and that older copepodite stages are more capable of buffering poor food quality than are younger copepodite stages, as recently suggested by Koshki et al. (2006). The quality of diet beyond the collapse may have also improved, enhancing the survival of remaining $N$. plumchrus. Further experiments are needed to test the effect of varying proportions of diatom- and flagellate-derived fatty acids on the somatic development of $N$. plumchrus at different copepodite stages. Nonetheless, the correlation between N. plumchrus abundance and DHA/EPA ratios suggests that an all-diatom diet decreases the survival of N. plumchrus in the SoG.

As in other coastal temperate systems, the pathway from diatoms to copepods to juvenile fishes in the SoG is thought to be one of the most efficient and productive trophic pathways, especially during the spring (Parsons et al. 1969, Parsons \& LeBrasseur 1970, Harrison et al. 1983). However, recent studies have suggested that diatoms may have been ascribed a more important dietary role than they warrant, and that omnivory is common and even beneficial to copepods (Kleppel 1993). Some studies have shown that diatoms impede several aspects of copepod reproduction 
(Jonasdottir et al. 1998, Ianora et al. 2003), either by the presence of toxic polyunsaturated aldehyde compounds or by the absence of essential fatty acids that are required for copepod growth (such as DHA) (Jonasdottir et al. 1998 and references therein). Whether diatoms are actually harmful to copepods or whether they are simply poor quality food, especially when they are not supplemented by other phytoplankton, is still very much under investigation (Ianora et al. 2003). Certainly, diatoms typically dominate the phytoplankton community during the spring bloom periods in the SoG, however, they are typically present with other phytoplankton groups (Stockner et al. 1979), which would allow for a diverse copepod diet. Our evidence suggests that in 2004-2005, the diversity of dietary items available to $N$. plumchus declined compared to 2002-2003. Recent evidence also suggests that the overwhelming diatom community in the spring of 2005 may have been nutrient-limited, which would exacerbate feeding on such a homogenous diet (Sastri \& Dower 2009).

The correlation between DHA/EPA ratios and abundance of Neocalanus plumchrus does not conclusively implicate poor food quality as the cause of decline of this copepod. However, it underscores how little we know about this aspect of copepod nutrition. Our results add strength to the call for more thorough experimentation on trophic dynamics, specifically the physiological thresholds of essential fatty acids that are required for somatic growth and reproduction of copepods (Ianora et al. 2003). Our results also show the benefit of including routine fatty acid measurements in long-term zooplankton monitoring projects, not just in highlighting physiological factors that contribute to population dynamics, but also as a means of generating testable hypotheses about the effect of food quality on somatic growth.

Acknowledgements. The authors thank the captains and crew of RV 'John Strickland' (University of Victoria) and CGGS 'Siyay' for assistance with sampling. C. Parrish, S. Verenitch and K. Young provided valuable technical advice for instrumentation, extraction and fatty acid identification. This research was supported by an NSERC Discovery Grant to J.F.D. and A.M., an NSERC Strategic Grant to S. Allen (STRATOGEM project). R.E-S. received funding from NSERC and The University of Victoria. The comments of 5 anonymous greatly improved this manuscript.

\section{LITERATURE CITED}

Ackman RG (1991) Application of gas-liquid chromatography to lipid separation analysis. In: Perkins EG (ed) Analysis of fats, oils and lipoproteins. American Oil Chemists' Society, Champaign, IL

Arendt KE, Jonasdottir SH, Hansen PJ, Gartner S (2005) Effects of dietary fatty acids on the reproduction success of the calanoid copepod Temora longicornis. Mar Biol 146: 513-530

Bell MV, Dick JR, Anderson TR, Pond DW (2007) Application of liposome and stable isotope tracer techniques to study polyunsaturated fatty acid biosynthesis in marine zooplankton. J Plankton Res 29:417-422

Bornhold EA (2000) Interannual and interdecadal patterns in timing and abundance of phytoplankton and zooplankton in the central Strait of Georgia, BC: with special reference to Neocalanus plumchrus. MSc thesis, The University of British Columbia, Vancouver, BC

- Bray JR, Curtis JT (1957) An ordination of the upland forest communities of southern Wisconsin. Ecol Monogr 27: 325-349

Budge SM, Parrish CC (1998) Lipid biogeochemistry of plankton, settling matter and sediments in Trinity Bay, NF. II. Fatty acids. Org Geochem 29:1547-1559

Campbell RW, Boutillier P, Dower JF (2004) Ecophysiology of overwintering in the copepod Neocalanus plumchrus: changes in lipid and protein contents over a seasonal cycle. Mar Ecol Prog Ser 280:211-226

Clarke KR (1993) Nonparametric multivariate analyses of changes in community structure. J Ecol 18:117-143

Dagg M (1993) Grazing by the copepod community does not control phytoplankton production in the subarctic Pacific Ocean. Prog Oceanogr 32:163-183

> Dalsgaard J, St John MA, Kattner G, Müller-Navarra D, Hagen W (2003) Fatty acid trophic markers in the pelagic marine environment. Adv Mar Biol 46:225-340

DFO (Department of Fisheries and Oceans) (2006) State of the Pacific Ocean 2005. Department of Fisheries and Oceans Canada, Ocean Status Report 2006/001, Pacific Region

El-Sabaawi RW, Kainz M, Mazumder A, Dower JF (2009) The trophic positions of calanoid copepods in the Strait of Georgia, British Columbia, Canada. Mar Biol 156:225-235

> Evanson M, Bornhold MA, Goldblatt RH, Harrison PJ, Lewis AG (2000) Temporal variability in body composition and lipid storage of the overwintering, subarctic copepod, Neocalanus plumchrus in the Strait of Georgia, British Columbia (Canada). Mar Ecol Prog Ser 192:239-247

Graeve M, Hagen W, Kattner G (1994) Herbivorous or omnivorous? On the significance of lipid compositions as trophic markers in Antarctic copepods. Deep-Sea Res Part I 41: 915-924

> Graeve M, Albers C, Kattner G (2005) Assimilation and biosynthesis of lipids in Arctic Calanus species based on feeding experiments with ${ }^{13} \mathrm{C}$ labeled diatom. J Exp Mar Biol Ecol 317:109-125

Hagen W, Kattner G, Graeve M (1995) On the lipid biochemistry of polar copepods: compositional differences in the Antarctic calanoids Euchaeta antarctica and Euchirella rostromagna. Mar Biol 123:451-457

Harrison PJ, Fulton JD, Taylor FJR, Parsons TR (1983) Review of the biological oceanography in the Strait of Georgia: pelagic environment. Can J Fish Aquat Sci 40:1064-1094

> Harrison PJ, Whitney FA, Tsuda A, Saito H, Tadokoro K (2004) Nutrient and phytoplankton dynamics in the NE and NW gyres of the subarctic Pacific Ocean. J Oceanogr 60:93-117

Ianora A, Poulet SA, Miralto A (2003) The effect of diatoms on copepod reproduction: a review. Phycologia 42:351-363

Jonasdottir SH, Kiorboe T, Tang KW, St. John M, Visser AW, Saiz E, Dam HG (1998) Role of diatoms in copepod reproduction: good, harmless or toxic? Mar Ecol Prog Ser 172: 305-308

> Jonasdottir SH, Trung NH, Hansen F, Gartner S (2005) Egg production and hatching success in the calanoid copepod 
Calanus helgolandicus and Calanus finmarchicus in the North Sea from March to September 2001. J Plankton Res 27:1239-1259

Kainz M, Arts MT, Mazumder A (2004) Essential fatty acids in the planktonic food web and their ecological role for higher trophic levels. Limnol Oceanogr 49:1784-1793

Kaneda T (1991) Iso- and anteiso-fatty acids in bacterial: biosynthesis, function and taxonomic significance. Microbiol Rev 55:288-302

Kattner G, Hagen W (1995) Polar herbivorous copepods: different pathways in lipid biosynthesis. ICES J Mar Sci 52: 329-335

Kattner G, Wehrtmann IS, Merck T (1994) Interannual variations of lipids and fatty acids during larval development of Crangon spp. in the German Bight, North Sea. Comp Biochem Physiol 107B:103-110

Klein Breteler WCM, Schogt N, Rampen S (2005) Effect of diatom nutrient limitation on copepod development: role of essential lipids. Mar Ecol Prog Ser 291:125-133

Kleppel GS (1993) On the diets of calanoid copepods. Mar Ecol Prog Ser 99:183-195

Kobayashi T, Takeuchi T, Arai D, Sekiya S (2000) Suitable dietary levels of EPA and DHA for larval mud crab during Artemia feeding period. Nippon Suisan Gakkai Shi 66: 1006-1013

Koski M, Breteler WK, Schogt N, Gonzalez S, Jakobsen HH (2006) Life-stage-specific differences in exploitation of food mixtures: diet mixing enhances copepod egg production but not juvenile development. J Plankton Res 28:919-936

Lee RF (1974) Lipids of zooplankton from Bute Inlet, British Columbia. J Fish Res Board Can 31:1577-1582

Lee RF, Hagen W, Kattner G (2006) Lipid storage in marine zooplankton. Mar Ecol Prog Ser 307:273-306

Lischka S, Hagen W (2007) Seasonal lipid dynamics of the copepod Pseudocalanus minutus (calanoida) and Oithona similis (Cyclopoida) in the Arctic Kongsfjorden (Svalbard). Mar Biol 150:443-454

Litzow MA, Bailey KM, Prahl FG, Heintz R (2006) Climate regime shifts and reorganization of fish communities: the essential fatty acid limitation hypothesis. Mar Ecol Prog Ser 315:1-11

Mackas DL, Peterson WT, Ohman MD, Lavaniegos BE (2006) Zooplankton anomalies in the California Current system before and during the warm ocean conditions of 2005 . Geophys Res Lett 33:L22S07

Masson D, Cummins PF (2007) Temperature trends and interannual variability in the Strait of Georgia, British Columbia. Cont Shelf Res 27:634-649

Mayzaud P, Chanut JP, Ackman RG (1989) Seasonal changes of the biochemical composition of marine particulate matter with special reference to fatty acids and sterols. Mar Ecol Prog Ser 56:189-204

Müller-Navarra DC, Brett MT, Liston AM, Goldman CR (2000) A highly unsaturated fatty acid predicts carbon

Editorial responsibility: Matthias Seaman, Oldendorf/Luhe, Germany transfer between primary producers and consumers. Nature 403:74-77

Parrish C (1999) Determination of total lipids, lipid classes and fatty acids in aquatic samples. In: Arts M, Wainmann BC (ed) Lipids in freshwater ecosystems. Springer, New York

Parsons TR, LeBrasseur RJ (1970) The availability of food to different trophic levels in the marine foodchain. In: Steele JH (ed) Marine food chains. Oliver \& Boyd, Edinburgh

Parsons TR, LeBrasseur RJ, Fulton JD, Kennedy OD (1969) Production studies in the strait of Georgia. Part II. Secondary production under the Fraser River plume. February to May, 1967. J Exp Mar Biol Ecol 3:39-50

Saito H, Kotani Y (2000) Lipids of four boreal species of calanoid copepods: origins of monoene fats of marine animals at higher trophic levels in the grazing food chain in the subarctic ocean ecosystem. Mar Chem 71:69-82

Sargent JR, Whittle KJ (1981) Lipids and hydrocarbons in marine foodwebs. In: Longhurst AR (ed) Analysis of marine ecosystems. Academic Press, London

Sastri A, Dower JF (2009) Interannual variability in chitobiase-based production rates of the crustacean zooplankton community in the Strait of Georgia, British Columbia, Canada. Mar Ecol Prog Ser (in press)

Scott CL, Kwansniewski S, Falk-Petersen S, Sargent JR (2002) Species differences, origins and functions of fatty alcohols and fatty acids in the wax esters and phospholipids of Calanus hyperboreus, C. glacialis and C. finmarchicus from Arctic waters. Mar Ecol Prog Ser 235:127-134

Sournia A (ed) (1978) Phytoplankton manual. UNESCO Monogr Oceanogr Methodol, Vol 6. UNESCO, Paris

St. John MA, Clemmesen C, Lund T, Köster T (2001) Diatom production in the marine environment: implications for larval fish growth and condition. ICES J Mar Sci 58: 1106-1113

Stevens CJ, Deibel D, Parrish CC (2004a) Incorporation of bacterial fatty acids and changes in a wax ester-based omnivory index during a long-term incubation experiment with Calanus glacialis Jaschnov. J Exp Mar Biol Ecol 303: 135-156

Stevens CJ, Deibel D, Parrish CC (2004b) Species-specific differences in lipid composition and omnivory in Arctic copepods collected in deep water during autumn (North Water Ploynya). Mar Biol 144:905-915

Stockner JG, Cliff DD, Shortreed KRS (1979) Phytoplankton ecology of the Strait of Georgia, British Columbia. Can J Fish Aquat Sci 36:657-666

Thompson PA, Guo M, Harrison PJ, Whyte JNC (1992) Effects of variations in temperature. II. On the fatty acid composition of eight species of marine phytoplankton. J Phycol 28: 488-497

Viso AC, Marty JC (1993) Fatty acids from 28 marine microalgae. Phytochemistry 34:1525-1533

Zar JH (1984) Biostatistical analysis. Prentice Hall, Saddle River, NJ

Submitted: March 26, 2008; Accepted: January 6, 2009 Proofs received from author(s): April 16, 2009 